\title{
O konieczności rzetelnego ustalania kontekstu rekonstruowanych emocji?
}

\author{
Jacek Jaguś, Ludność białoruska województwa nowogródzkiego II \\ Rzeczypospolitej w percepcji polskich elit regionu. Analiza społeczno-polityczna, \\ Adam Marszałek, Toruń 2014, ss. 275.
}

Interdyscyplinarność jest częścią obowiązującego obecnie paradygmatu badawczego humanistyki. Wpisuje się w tendencję do przekraczania granic między dyscyplinami, a w każdym razie do spostrzegania problemów i zagadnień, których z jednorodnego punktu widzenia widać by nie było. Interdyscyplinarność stała się więc obecnie synonimem zaawansowanych badań naukowych i przyjmuje się a priori, że jeśli jakieś badanie jest interdyscyplinarne, to musi się cechować wysoką jakością. Przy podejmowaniu tematów interdyscyplinarnych warto jednak pamiętać o niebezpieczeństwie powierzchownego przyswojenia sobie niektórych metod stosowanych w poszczególnych naukach. Opanowanie warsztatu paru dyscyplin naukowych nie jest rzeczą łatwą. Jak wiadomo, nie ma jak dotąd metodologii interdyscyplinarnej. Eklektyzm odrębnych metodologii stosowany nierzetelnie i bez należytej kontroli nieraz prowadzić może na manowce.

Temat badawczy określony w tytule recenzowanej pracy Jacka Jagusia sformułowany został bardzo interesująco i brzmi „Ludność białoruska województwa nowogródzkiego II Rzeczypospolitej w percepcji polskich elit regionu. Analiza społeczno-polityczna”. Autor jest z wykształcenia politologiem (absolwentem Uniwersytetu Wrocławskiego) i socjologiem (absolwentem UMCS), a także historykiem (absolwentem Wyższej Szkoły Pedagogicznej w Kielcach). Praca jest dysertacją doktorską pisaną na Uniwersytecie Wrocławskim pod opieką Profesora Z. Winnickiego, który reklamuje swego doktoranta w sposób następujący: „Praca dr. Jacka Jagusia jest monografią w pełni nowatorską, opartą na badaniach źródłowych (archiwaliach) i dostępnej literaturze przedmiotu [--] Ma charakter interdyscyplinarny, ukazujący badane zjawisko w aspekcie historycznym, politologicznym oraz socjologicznym [--] praca jest napisana wyjątkowo starannym, merytorycznym językiem naukowymi jednocześnie w pełni komunikatywnym"1.

O staranności języka Autora pracy mam nieco odmienne zdanie, ale nie to jest tu najważniejsze. Jacek Jaguś użył w swojej książce wiedzę i narzędzia z kilku dziedzin w nadziei - jak rozumiem - na wspomożenie interpretacji opisywanych przez siebie zjawisk. Nie mam wykształcenia socjologicznego. Pozostaje mi więc do rozstrzygnięcia kwestia, czy w prezentowanej pracy przedstawiona została analiza obrazu zrekonstruowanego - z punktu widzenia historyka - rzetelnie.

We wstępie J. Jaguś nie uzasadnia wyboru do analizy województwa nowogródzkiego, jak wiadomo tradycyjnie charakteryzującego się największą liczbą ludności świadomej swej białoruskości. Więcej, wyniki swych analiz i wysnuwane wnioski - z licznymi co prawda „Zastrzeżeniami” - Autor konsekwentnie rozciąga na całe terytorium Ziem Wschodnich ${ }^{2}$.

1 „Z recenzji dr. hab. prof. UWr Zdzisława J. Winnickiego” umieszczonej na okładce omawianej książki.

2 „wybrane problemy [--] poddano analizie odnosząc się do całego obszaru II RP zamieszkiwanego przez Białorusinów” s. 10 wstępu i inne; s. 7 przypis 2 „analizy niniejsze obejmują cały okres międzywojenny, tj. lata 


\section{Struktura pracy}

Pierwszy rozdział liczy stron 14 i zawiera opis metody i bazy źródłowej.

Drugi rozdział liczy stron 40 i w pięciu podrozdziałach przedstawia charakterystykę województwa nowogródzkiego. W podrozdziale pierwszym tego rozdziału omówiona została literatura powstała od momentu zakończenia I wojny światowej (Wielkiej Wojny). W podrozdziałach pozostałych przeprowadzono analizę województwa nowogródzkiego ze szczególnym uwzględnieniem: podziału administracyjnego i jego zmian, liczby ludności i gęstości zaludnienia, urbanizacji i industrializacji, oświaty i szkolnictwa, struktury wyznań i narodowości, białoruskich organizacji politycznych, gospodarczych i społecznych.

Trzeci rozdział liczący stron 28 podzielony jest na cztery podrozdziały i poświęcony jest przedstawieniu - tak jak to widzi Autor - postrzegania Białorusinów przez polskie elity. W pierwszym podrozdziale tego rozdziału J. Jaguś zamierzał omówić historyczne źródła postrzegania przedstawicieli mniejszości, od 1918 roku. Treścią podrozdziału drugiego są kwestie liczebności, przestrzennej zwartości oraz położenia społeczno-ekonomicznego Białorusinów. Podrozdział trzeci poświęcony jest analizie problemu stanu świadomości narodowej Białorusinów. Podrozdział czwarty dotyczy instytucjonalizacji życia społecznego mniejszości białoruskiej w okresie międzywojennym. W podrozdziale piątym omówiono rolę czynnika BSRR i propagandy ZSRR. W podrozdziale szóstym scharakteryzowano wpływ polityki narodowościowej prowadzonej przez Polaków wobec Białorusinów - tu znalazło się omówienie koncepcji polskiej polityki narodowościowej i jej ewolucja w latach 1918-1939.

Czwarty rozdział - najobszerniejszy, bo 104-stronicowy - zawiera, jak deklaruje Autor, rekonstrukcję portretu zbiorowego Białorusinów „na podstawie opisów pamiętnikarskich”. Autor zwrócił szczególną uwagę na stosunek Białorusinów do państwa polskiego (podrozdział pierwszy); stan rozwoju świadomości narodowej wśród Białorusinów (podrozdział drugi) i cechy osobowe Białorusinów (podrozdział trzeci).

Celem rozdziału piątego jest „wskazanie wartości poznawczej” tego, co sam Autor napisał w rozdziałach I-IV. Analizy dokonuje on w oparciu o „przywołanie kluczowych ustaleń dotyczących okresu międzywojennego”. Ta analiza jest według niego kluczem do zrozumienia „postaw i zachowań Białorusinów, zarówno w latach 1918-1939, w latach II WW i współcześnie"3.

Prawdę powiedziawszy, nie wiem, w jakim celu powstała ta książka. Wybrane przez Autora fragmenty czyta się na pewno z zainteresowaniem i - w wypadku osoby, która zna „aspekt historyczny” poruszanej tematyki, opracowania, a przede wszystkim źródła - nie ukrywam, z rosnącą irytacją.

J. Jaguś przedstawia cel swojej analizy w sposób następujący. Cytuję: „W niniejszych rozważaniach jednostkę analizy stanowi indywidualna percepcja Białorusinów” (s. 26). Pisze dalej: „Kluczową kwestią dla realizacji zasadniczego celu niniejszej pracy jest przedstawienie obrazu Białorusinów w oczach polskich elit”. I dodaje: „Problem jego [obrazu] zgodności ze stanem faktycznym, choć stanowi poznawczo istotną kwestię, dla analiz odnoszących się do rekonstrukcji percepcji Białorusinów, nie odgrywa kluczowej roli. Tym samym interesującym dla nas źródłem, w kontekście rozważań zaprezentowanych w rozdziale czwartym, jest określony sposób postrzegania Białorusinów, niezależnie od tego, na ile stanowi on odbicie faktycznych cech czy procesów występujących wśród przedstawicieli”.

1918-1939”; s. 11. „etap pierwszy to okres od momentu objęcia w 1919 roku władzy przez państwo polskie na terenach późniejszego województwa nowogródzkiego".

3 Patrz tekst Wstępu oraz autorskiej informacji na tylnej okładce omawianego tomu. 
Autor kładzie nacisk na szczególną wagę (s. 27), jaką przykłada do dokumentów osobistych, za które uważa wyłącznie pamiętniki, i przyznaje, że teksty analizowane przez niego w pracy zostały spisane w dużym odstępie czasowym, „niekiedy sięgającym kilkudziesięciu lat od opisywanych wydarzeń" i „fakt ten stanowi oczywiście czynnik obniżający wiarygodność analizowanych pamiętników”. J. Jaguś sam zauważa, że ten dystans mógł wpłynąć na wyznawane wcześniej przez tych ludzi opinie o Białorusinach. Autor zastrzega kilkakrotnie, m.in. na s. 18: „Oczywiście badania niniejsze nie zyskują waloru badań reprezentatywnych. Wręcz przeciwnie”. Ale - na następnej stronie (s. 19) - bynajmniej nierażony, kontynuuje, iż praca „nie ogranicza się jedynie do rekonstrukcji obrazu Białorusinów Nowogródczyzny okresu międzywojennego w percepcji polskich elit regionu. Podjęto tu także próbę wykorzystania zrekonstruowanego obrazu do zrozumienia postaw i zachowań Białorusinów w okresach późniejszych, włączając w to dzień dzisiejszy”.

J. Jaguś pisze ponownie (s. 28 i dalej): „Oczywiście nawet w przypadku wykorzystania różnych rodzajów źródeł nasza próba nie jest próbą reprezentatywną. Tym samym, precyzyjnego twierdzenia o stopniu rozpowszechnienia się wśród Polaków [czyli już nie tylko Polaków z Nowogródczyzny - podkr. jgk] przeświadczenia, że Białorusini charakteryzują się taką czy inną cechą, nie da się praktycznie przedstawić. Niemniej z bardzo dużą dozą prawdopodobieństwa, w oparciu o przeprowadzone badania, można stwierdzić, że określone cechy były znacznie bardziej powszechne w polskim obrazie [jw. - podkr. jgk] Białorusinów, niż inne”. Autor zastrzega też: „Jednocześnie wyraźnie należy zaznaczyć, iż stwierdzenie stopnia rozpowszechnienia określonej cechy w obrazie Białorusinów Nowogródczyzny nie stanowi zasadniczego celu niniejszej książki”.

J. Jaguś nie ukrywa, iż rozważania dotyczące wiarygodności i rzetelności wykorzystywanych źródeł historycznych opiera przede wszystkim na pracach socjologów i politologów (A. Sułek, M. Ogryzko-Wiewiórkowska, J. R. Sielezin, A. J. Chodubski - przypis 30 na s. 23). Powołuje się też na refleksję J. R. Sielezina „Badacz nie powinien wykluczać źródeł sfałszowanych, cząstkowo tylko odzwierciedlających społeczną rzeczywistość, gdyż nawet taki dokument jest niekiedy ważnym źródłem poznawczym” (przypis 39, s. 26).

Historykowi pozostaje zadać pytanie, czy w oparciu - jak ujmuje J. Jaguś - o „źródła zastane" zrekonstruowany został przez niego rzeczywisty obraz postrzegania Białorusinów przez polskie elity, zarówno te $\mathrm{z}$ występującego w tytule pracy - województwa nowogródzkiego, jak też, podążając za tokiem myśli Autora, polskie elity w całości?

Odnoszę wrażenie, że Jaguś celowo nie „wywołuje” niektórych, pozostających w trakcie pisania pracy jeszcze w zasięgu, potrzebnych źródeł. Unika w ten sposób konfrontacji wykreowanego przez siebie obrazu z pamięcią o epoce rzetelnych i obiektywnych historyków o niekwestionowanym dorobku naukowym. Żyje i funkcjonuje nadal zawodowo w historycznym środowisku warszawskim (mamy rok 2015) dwóch Nowogródczan, klasycznych reprezentantów polskich elit Nowogródczyzny, o których to elit „opinii” pisze J. Jaguś. Są to prof. Romuald Wojna i dr Henryk Bułhak. Myślę, że w chwili powstawania pracy dr. Jagusia (co, sądząc z wpisów w metryczkach archiwalnych, trwało przynajmniej od początków 2004 r.) można było znaleźć jeszcze i innych Nowogródczan, chociażby w środowiskach pozawarszawskich. Położenie geopolityczne Polski i zmiany jej granic w XX w. sprawiły, że większość dokumentów, pamiątek, wspomnień czy listów dotyczących historii ziem, które z różnych względów i nie tylko w wyniku działań wojennych totalnie zmieniły swoje oblicze i charakter, została bezpowrotnie zniszczona. To, co ocalało, znajduje się dziś poza granicami Polski, jest trudno uchwytne i mało dostępne dla historyków. W tej sytuacji jest oczywiste, 
iż z pieczołowitością powinniśmy chronić i zabezpieczać dla potomnych wszystko, co leży w zasięgu naszych możliwości. Temat, którego realizacji podjął się J. Jaguś, stwarzał ku temu możliwości, niestety niewykorzystane przez Autora. W zasadzie bezpowrotnie straciliśmy szansę na wytworzenie przez J. Jagusia tzw. źródeł prowokowanych.

J. Jaguś definiuje, co rozumie pod terminem „grono elity Nowogródczyzny” i z metodologicznego punktu widzenia jest to posunięcie bardzo słuszne. Autor przyjmuje, że do grona występujących w tytule pracy „polskich elit regionu” należeli wszyscy urzędnicy, pracownicy naukowi, nauczyciele, studenci, duchowni, publicyści, oficerowie Wojska Polskiego, policji i Korpusu Ochrony Pogranicza oraz ziemianie. Na taką klasyfikację można się zgodzić z kilkoma zastrzeżeniami. Znanych mi żyjących Nowogródczan zaskoczyła informacja o pracownikach naukowych w mieście, w którym w całym Dwudziestoleciu nie było placówki naukowej wyższej stopniem od Państwowego Gimnazjum im. Adama Mickiewicza (dyrektorem którego w latach 1934-1937 był Józef Rybicki ${ }^{4}$. Mnie zabrakło tu - co najmniej - sędziów, adwokatów, notariuszy, lekarzy, aptekarzy i weterynarzy.

Niestety, Autor nie definiuje, co rozumie pod pojęciem „ludność białoruska”. Odnoszę wrażenie, że analizując materiał, utożsamia mieszkańców białoruskich ziem byłego Wielkiego Księstwa Litewskiego w roku 1918 z mieszkańcami tzw. Białorusi Zachodniej w 1939 roku. Tak generalizującej przedmiot badania formuły z punktu widzenia historyka przyjąć po prostu nie można.

Autor rozciąga swoje spostrzeżenia na całe Dwudziestolecie, które zaczyna się dla niego i słusznie - w początkach roku 1919, jeśli nie w chwili zakończenia Wielkiej Wojny. Odstąpienie przez Autora od bardzo ostatnio powszechnie przyjmowanych przez historyków ram czasowych Dwudziestolecia jest w mojej ocenie jak najbardziej uzasadnione merytorycznie. Praca - poza najobszerniejszym rozdziałem czwartym - oparta jest jednak w dużej mierze na opracowaniach dotyczących Dwudziestolecia w przyjmowanych ramach chronologicznych - 1921-1939. A przecież literatura dotycząca tematu dla lat 1918-1920 jest obszerna.

Autor (i słusznie) polemizuje w szczegółach z E. Mironowiczem i K. Gomółką, przytacza wybrane przez siebie wartościowe prace W. Śleszyńskiego czy M. Kurkiewicza, (sporadycznie) J. Jurkowskiego, (często) Z. Winnickiego i E. Kirwiel czy J. Grzybowskiego (w części dot. II WW). Wszyscy wymienieni Autorzy, choć nie obejmują w cytowanych przez J. Jagusia analizach dotyczących okresu lat 1919-1920, to jednak przywołują na stronicach swoich opracowań zignorowaną przez J. Jagusia obszerną pracę poświęconą polityce wschodniej Józefa Piłsudskiego w latach 1919-19205, w której bardzo dużo uwagi poświęcono kwestii białoruskiej. Zabrakło też miejsca dla pracy Joanny Januszewskiej-Jurkiewicz ${ }^{6}$, której znacząca część poświęcona jest kwestii białoruskiej. Praca J. Jagusia wydana jest w roku 2014, powinna więc uwzględniać bezcenną pozycję opublikowaną w pierwszym półroczu roku 2013 - Seweryna Wysłoucha Stosunki narodowościowe na terenie województw wschodnich7. Nie uwzględnia.

4 Józef Roman Rybicki 1901-1986, filolog klasyczny (USB), nauczyciel, żołnierz AK ps. Andrzej - dowódca Kedywu Okręgu Warszawa, uczestnik Powstania Warszawskiego, członek WiN, więzień polityczny w latach 1945-1954, współzałożyciel KOR.

5 J. Gierowska-Kałłaur, Zarząd Cywilny Ziem Wschodnich (19 lutego 1919 - 9 września 1920), Neriton \& Instytut Historii PAN, Warszawa 2003, ss. 447.

6 J. Januszewska-Jurkiewicz, Stosunki narodowościowe na Wileńszczyźnie w latach 1920-1939, Prace Naukowe Uniwersytetu Śląskiego w Katowicach, nr 2691,Wydawnictwo Uniwersytetu Śląskiego, Katowice 2010, ss. 712.

7 S. Wysłouch, Stosunki narodowościowe na terenie województw wschodnich [Wilno 1939/40], red. naukowy M. Iwanow, Studium Europy Wschodniej, Uniwersytet Warszawski, Warszawa 2013, Bibliotheca Europae Orientalis 42, Fontes 3, ss. LXX, 303. 
Zagadnieniem stosunku polskiej elity do ludności białoruskiej - w bardzo wąsko zakreślonych ramach problemu - zajmowało się już kilkoro badaczy. Autor przytacza niektórych z nich, wymieniam chronologicznie: J. Tomaszewski (Białorusini w oczach Polaków 1918-1939, „Literatura na Świecie” 1991); J. Jurkiewicz (Nasze widzenie Białorusinów w XX w., „Dzieje Najnowsze” 1995), R. Radzik (Kim sa Białorusini, Toruń 2002).

W bibliografii uwzględniono prace znakomitych polskich historyków (J. Żarnowski Epoka dwóch wojen; Wokót stereotypów Polaków i Niemców, red. W. Wrzesiński; Wajda, Polski obraz Niemców i niemiecki obraz Polaków w publicystyce; R. Wapiński, Polska na styku kultur i narodów; T. Szarota, Polak $w$ karykaturze niemieckiej i in.), ale nie są to prace dotyczące bezpośrednio relacji polsko-białoruskich. Chyba jednak przydatne do podjętego tematu byłyby dwa teksty: Białorusini czy Moskale? Ludność miejscowa Białorusi w świetle raportów Straży Kresowej8 oraz Polacy i Białorusini we wzajemnych opiniach w latach 1918-19219? Autor nie uwzględnił też ważnych dla podjętej tematyki opublikowanych w Polsce artykułów białoruskiego badacza Andreja Krotaua - Geneza białoruskiego stereotypu Polski i Polaków10 oraz - Obraz Polaków w prasie białoruskiej lat dwudziestych11. J. Jaguś przytacza w bibliografii chyba najbardziej znaną książkę Krystyny Gomółki i jej trzy artykuły z Białoruskich Zeszytów Historycznych ${ }^{12}$, ale milczeniem pomija ważniejsze wystąpienie tej badaczki dla poruszanego przez siebie tematu - tekst Ruch białoruski w przededniu wybuchu II wojny światowej13.

Stosunkiem polskiej elity Nowogródczyzny do ludności białoruskiej województwa nowogródzkiego, w ścisłym i wąskim ujęciu tematu, zajmował się dotąd istotnie jedynie J. Jaguś ${ }^{14}$. Jednak uwaga Autora - „Stan badań na temat obrazu Białorusinów w percepcji Polaków w okresie międzywojennym [już nie tylko w woj. nowogródzkim - jgk] jest bardzo ubogi. W zasadzie literaturę tematu wyczerpują cztery prace, w tym trzy artykuły [Tomaszewski, Jurkiewicz, Radzik] i podrozdział w publikacji zwartej [Jaguś]” - jest co najmniej nie na miejscu.

Nie należy tracić z pola widzenia autorów prac, z ustaleń których dr J. Jaguś korzysta w swoim tekście. Są to przedwojenne prace: drukowane J. Zaremby, Stosunki narodowościowe w województwie nowogródzkim z uwzględnieniem tła socjalnego (Warszawa 1939), które są cytowane co najmniej $33 \mathrm{razy}^{15}$, również drukowane S. Poczobutt- Odlanickiego,

8 J. Gierowska-Kałłaur, Białorusini czy Moskale? Ludność miejscowa Białorusi w świetle raportów Straży Kresowej, „Studia z Dziejów Rosji i Europy Środkowo-Wschodniej” 48, 2013, s. 44-77.

9 J. Gierowska-Kałłaur, Polacy i Białorusini we wzajemnych opiniach w latach 1918-1921, „Studia z Dziejów Rosji i Europy Środkowo-Wschodniej” 42, 2007, s. 35-66.

10 A. Krotau, Geneza białoruskiego stereotypu Polski i Polaków, tł. z ros. A. Szczęsny, „Przegląd Wschodni”, t. 8, z. 1. (2002), s. 57-74.

11 A. Krotau, Obraz Polaków w prasie białoruskiej lat dwudziestych, tł. z białorus. E. Szymczuk, „Sprawy Narodowościowe" 1996 z. 1, s. 193-207.

12 K. Gomółka, Białorusini w II Rzeczypospolitej, „Zeszyty Naukowe Politechniki Gdańskiej”, Ekonomia, nr 31, 495, Gdańsk 1992 oraz tejże trzy artykuły: Białoruskie instytucje życia gospodarczego („Białoruskie Zeszyty Historyczne”, dalej: BZH, 1997, z. 8); Białoruskie partie i organizacje prorzadowe w II Rzeczpospolitej (BZH 1997, z. 7); Polityka rządów polskich wobec mniejszości białoruskiej w latach 1918-1939 (BZH 1995, z. 4).

13 K. Gomółka, Ruch białoruski w przededniu wybuchu II wojny światowej, [w:] Studia i szkice z dziejów najnowszych, red. M. Tanty, Warszawa 1989.

14 J. Jaguś, Białorusini Nowogródczyzny w oczach polskich sasiadów (1918-1939), [w:] Białoruś. Przeszłość i teraźniejszość. Kultura-Literatura-Język, red. R. Radzik, M. Sajewicz, Wydawnictwo UMCS, Lublin 2010, s. 49-60.

15 Rozdział II omawianej pracy, przypisy: 4, 5, 7, 8, 9, 11, 16, 17, 18, 24, 26, 27, 28, 29, 30, 63, 64, 66, 70, 78, $79,80,81,82,84$; rozdział III omawianej pracy, przypisy: 14, 42; rozdział IV omawianej pracy, przypisy: 36,43 , $51,61,66,69$. 
Województwo Nowogródzkie (Wilno 1936), cytowane co najmniej 20 razy ${ }^{16}$ i praca dyplomowa SGH z 1932 r. H. Szlamińskiej (Monografia województwa nowogródzkiego) cytowana co najmniej 8 razy $^{17}$. Te opracowania są obszernie przywoływane, a efekt końcowy uważam za duży walor omawianej pracy. Do tych trzech opracowań należałoby dołączyć pracę dyplomową słuchacza Szkoły Nauk Politycznych Władysława Milanowskiego wykonaną w 1924 r. pod kierunkiem St. Srokowskiego, uwzględnioną w bibliografii jedynie jako spuścizna, a nie opracowanie naukowe. Dodajmy, że narracja J. Jagusia wzbogacona jest przypisami rzeczowymi, gdzie źródła informacji autor nie podaje i nasuwa się przypuszczenie, że informacje są przez niego zaczerpnięte w dużej części właśnie z wyżej wymienionych opracowań.

Głębiej można by przeanalizować poruszany przez J. Jagusia temat szkolnictwa białoruskiego, jeśliby wykorzystać wydane w latach ostatnich (po białorusku) prace białoruskich autorów o szkolnictwie na Ziemiach Wschodnich (m.in. W. Lachouski, S. Troubczyk i in. ${ }^{18}$ ).

J. Jaguś utrwala różne występujące w literaturze stereotypy. Pisze m.in.: „dopiero Niemcy podczas okupacji wschodnich terenów Polski podjęli próbę, ze względów politycznych, utworzenia białoruskich szkół” (s. 41).

Pierwszą moją uwagą jest uwaga „techniczna” - Ober-Ost nie okupował w latach 1915-1918 wschodnich terenów Polski, tylko część ziem byłej Rzeczypospolitej Obojga Narodów. Uwaga druga - wbrew temu, co pisze Autor, mitem jest owe tworzenie białoruskich szkół przez Niemców „ze względów politycznych”.

Pierwszy okres Ober-Ostu istotnie jest bardzo pozytywnie postrzegany przez historyków białoruskich. Uważają, nie bez racji, iż Białorusini byli beneficjentami zreformowanej przez Niemców na przełomie XII 1915/I 1916 nowej organizacji szkolnictwa. Mniej powszechna jest świadomość, że nie byli to jednak jedyni beneficjenci tej reformy, a jej politycznym celem było nie wspieranie ruchu białoruskiego, tylko wyeliminowanie języka dotychczasowego okupanta. Niemcy wprowadzili zakaz nauki w języku rosyjskim. W konsekwencji pojawiła się konieczność nowej organizacji szkolnictwa. Wprowadzono więc obowiązkowe nauczanie w językach narodowych dla wszystkich rdzennych narodów Ober-Ostu. W Wilnie istotnie otwarto pierwszą początkową szkołę białoruską. Historiografia białoruska pomija absolutnym milczeniem fakt (a J. Jaguś powtarza to za nią w sposób bezrefleksyjny), iż inne narodowości też mogły otwierać swoje szkoły. Jednocześnie z pierwszą powszechną szkołą białoruską otwarto w Wilnie cztery polskie gimnazja, osiem progimnazjów, 30 polskich szkół początkowych. Ponieważ pojawiło się, chociaż niewielkie, zapotrzebowanie na szkoły białoruskie, a brakowało kadr nauczycielskich białoruskich, więc Niemcy istotnie otworzyli w Świsłoczy na Grodzieńszczyźnie jedno seminarium nauczycielskie, gdzie w czasie całej niemieckiej okupacji wykształciło się w sumie 144 nauczycieli białoruskich. To „tworzenie szkolnictwa białoruskiego ze względów politycznych" nie kolidowało z jednoczesnym rozwiązaniem przez Niemców wszystkich organizacji białoruskich (łącznie ze związkiem Nauczycieli Białoruskich) i o tym raczej w publikacjach białoruskich badaczy nie czytamy... A z białoruskiego „Homana” (numer z czerwca 1916) dowiadujemy się, że od początku roku szkolnego 1916/1917 Niemcy wprowadzili segregację w szkołach białoruskich. Nakazano skrupulatne oddzie-

16 Rozdział II omawianej pracy, przypisy: 21, 12, 10, 7, 6, 3, 22, 31, 32, 33, 41, 47, 48, 54, 53, 62, 65, 83, 88.

17 Rozdział II omawianej pracy, przypisy: 40, 45, 48, 56, 58, 59, 61, 73.

$18 \mathrm{Na}$ marginesie - białoruscy autorzy, w przeciwieństwie do J. Jagusia, docenili wartość pozostających do 2003 r. poza obiegiem materiałów archiwalnych i ich analizę zawartą w obszernym rozdziale Szkolnictwo na ziemiach podległych jurysdykcji ZCZW we wspomnianej już pracy o Zarządzie Cywilnym Ziem Wschodnich. 
lanie dzieci prawosławnych od dzieci katolickich. Zaiste, przejaw to wybitnej „probiałoruskości” polityki niemieckiej w tym czasie!

Dla okresu międzywojennego (cezura 1918-1939) autor konstatuje naprawdę zbyt ogólnikowo - „problem wyglądał różnie w poszczególnych latach” (s. 41). [--] „Ogólnie jednak trzeba stwierdzić nieproporcjonalnie małą liczbę szkól białoruskich w stosunku do liczebności tej mniejszości”. Za stan ten autor obwinia dwa czynniki - niski stan świadomości narodowej Białorusinów oraz politykę polskich władz wobec mniejszości białoruskiej.

Szkoda, że Autor nie dotarł do opartego na precyzyjnych i unikalnych dokumentach opracowania Szkolnictwo na ziemiach podległych Zarzadowi Cywilnemu Ziem Wschodnich19. W przedstawionych tam danych J. Jaguś znalazłby m.in. dowód na to, że szkolnictwo białoruskie nie tylko nie było ograniczane, a nawet - w porównaniu z pozostałymi grupami narodowymi - cieszyło się w latach 1919-1920 wyraźnym poparciem, dodajmy - z wyraźną szkodą dla polskiego szkolnictwa w Mińsku oraz polskich i niepolskich szkół powszechnych w Okręgu Brzeskim ZCZW. Ludność zamieszkująca ziemie białoruskie nie była po prostu w stanie wykorzystać tej szansy, preferując nauczanie w językach innych niż białoruski. Oczywiście, J. Jaguś ma prawo do własnej interpretacji, dyskusja naukowa nigdy jednak nie polegała i nadal nie polega na ignorowaniu istnienia źródeł i opracowań niewygodnych dla obranej przez siebie tezy.

Z tekstu J. Jagusia niezbicie wynika, że Autor niewiele wie o polityce wschodniej J. Piłsudskiego w latach 1919-1920. Pisze we wstępie: „czołowi polscy politycy z J. Piłsudskim na czele, nie wykazywali szczególnego zainteresowania zagadnieniami mniejszości białoruskiej” (s. 8). Pisze też w zakończeniu: „cechą charakterystyczną polityki narodowościowej wobec Białorusinów II Rzeczypospolitej [1918-1939] jest niewielkie zainteresowanie tą mniejszością ze strony czołowych polskich polityków, z J. Piłsudskim na czele” (s. 257). Autor książki wydanej drukiem w 2014 r. w Polsce nie orientuje się w przebiegu wydarzeń w okresie i na terenie, które są przedmiotem jego dysertacji doktorskiej. J. Jaguś po prostu nie wie, iż w latach wojny polsko-sowieckiej Józef Piłsudski wbrew swoim politycznym oponentom, a także w sporej części wbrew polskim mieszkańcom ziem byłego WXL i dodatkowo - przy niezrozumieniu swoich intencji zarówno przez białoruskich polityków, jak i przez białoruskie masy, w ramach szerszego projektu prowadził w kilku odsłonach naprawdę intensywną politykę probiałoruską. A jej finalne niepowodzenie nie było wyłącznie polską winą. J. Jaguś jest głęboko przekonany (s. 11), że państwo polskie objęło władzę w Nowogródczyźnie w 1919 roku! Czyli „nie było” Zarządu Cywilnego Ziem Wschodnich, „nie było” pierwszych „stu dni Litwy Środkowej”... No comment.

Do mas białoruskich świadomość intencji Piłsudskiego dotarła z dużym opóźnieniem. Ale w końcu dotarła. I dlatego z niedowierzaniem czytam wywody J. Jagusia przedstawione na stronach omawianej książki: „Fakt popularności marszałka J. Piłsudskiego wśród Białorusinów jest ciekawym, jak należy przypuszczać [podkr. jgk], wskaźnikiem ich stosunku do władzy w ogóle. Mamy tu zapewne [podkr. jgk] do czynienia z reminiscencją bezkrytycznego stosunku do cara i przenoszenia odpowiedzialności za swoje ewentualne krzywdy na otoczenie głowy państwa” (s. 129). Taki oto obraz polskiej polityki wschodniej wykreowany w oparciu o niepełną polską literaturę przedmiotu upowszechniany jest w roku 2015.

Źródła drukowane są w tej pracy w zasadzie wykorzystane (oprócz wspomnianego już braku fundamentalnej pracy Seweryna Wysłoucha), choć oczywiście zawsze można by kwe-

19 J. Gierowska-Kałłaur, Szkolnictwo na ziemiach podległych Zarządowi Cywilnemu Ziem Wschodnich, [w:] Zarząd Cywilny Ziem Wschodnich (19 lutego 1919 - 9 września 1920), Neriton \& Instytut Historii PAN, Warszawa 2003, s. 216-254. 
rendę poprowadzić szerzej. Szkoda, że umknęły uwadze Autora drukowane Wspomnienia lidzianina - urodzonego w 1920 r. Władysława Naruszewicza (Bellona 2001) czy urodzonej w 1916 r. Marii Jeśman - Zielone lata: Nowogródek 1921-1934 (Gdańsk-Gdynia 2000). Przy tak szeroko realizowanym temacie może należałoby wykorzystać także Henryka Jana Józewskiego, Z Kresów Wschodnich. Wspomnienia z osad wojskowych 1921-1940 (red. H. Łappo, Londyn 1972).

Przydałaby się jakaś forma charakterystyki występujących w tytule polskich elit Nowogródczyzny. Czy Białorusini jako grupa nie byli również obiektem badań i pasji przedstawicieli tych elit, czy też tylko i wyłącznie przedmiotem krytycznych ocen?

Ciekawych materiałów (uwaga - dotyczących wyłącznie Nowogródczyzny) tylko w Bibliotece Narodowej w Warszawie znajduje się naprawdę wiele. Oto niektóre z nich: Tadeusz Jacek Rolicki, Kijem w mrowisko: (satyry na Nowogródek), Nowogródek 1936 i tegoż Szopka Nowogródzka (Nowogródek 1935); Wanda Bieniewska, Gry i zabawy Ziemi Nowogródzkiej (Nowogródek 1937), Pieśni ludowe ziemi wileńskiej i nowogródzkiej w opracowaniu Bronisławy Gawrońskiej (Wilno 1935).

Może warto byłoby uwzględnić przy takim tytule dysertacji - chociażby w bibliografii trzykrotnie aktualizowaną przed wojną pracę Józefa Żmigrodzkiego Nowogródek: zarys historyczny (Wilno 1924, 1927, 1931) lub Strony nowogródzkie: szkice krajoznawcze Władysława Abramowicza (Lida 1938)? Są jeszcze i inne prace dotyczące Nowogródka i Nowogródczyzny.

Generalną zaletą omawianej pracy miało być przedstawienie problemu po przeprowadzeniu analizy źródeł archiwalnych. Źródła urzędowe w zasadzie wykorzystane zostały jednak tylko w najobszerniejszym, czwartym rozdziale. Na marginesie - bardzo zabawna jest quasi definicja źródła urzędowego w wykonaniu Autora, cytuję: „Dokumenty urzędowe poddane analizie powstały w instytucjach, dla których produkcja dokumentacji nie stanowi ich zasadniczego zadania" (s. 22).

Autor ograniczył swoją kwerendę do Warszawy - przypuszczalnie prowadził ją wyłącznie w Dziale Rękopisów Biblioteki Narodowej i w Archiwum Akt Nowych.

Nawiązując do rozważań J. Szczepańskiego, a szczególnie do wyróżnionych przez tego badacza pięciu sposobów postępowania podczas analizy dokumentów osobistych, J. Jaguś doszedł do wniosku, że metoda przyjęta w pracy jest zbliżona do metody konstruktywnej polegającej na studiowaniu możliwie wielkiej ilości autobiografii pod kątem widzenia określonego problemu. Jak pisze Autor, „czytając autobiografie, socjolog dokonuje pewnej ich reinterpretacji z punktu widzenia jakiejś ogólnej teorii socjologicznej, a poszczególne opisy stają się elementami składowymi, z których konstruuje ogólny obraz zjawisk" (s. 17). Zestaw wybranych przez J. Jagusia pamiętników jest - jak zawsze - wyborem subiektywnym. Wydaje się jednak, że jedyne kryterium wyboru stanowiło dla Autora miejsce przechowywania - Warszawa.

J. Jaguś deklaruje oparcie badań na dwudziestu pamiętnikach i opracowaniach przechowywanych w zbiorach BN w Warszawie. Brak w tekście choć rudymentarnych danych osobowych o autorach, których dodatkowo J. Jaguś pozbawił imion, podając jedynie inicjały.

Prawnik i oficer WP Jan Bieńkiewicz (a nie Bieńkowski), syn Henryka Bieńkiewicza, starosty słonimskiego z 1939 r., jest autorem 61-stronicowego maszynopisu „Wspomnienia Słonimiaka” (sygn. BN 013595). (Pamiętnik Bieńkowskiego, niemającego żadnego związku z omawianym tematem, jest wymieniony w drukowanym katalogu rękopisów BN bezpośrednio za Janem Bieńkiewiczem, stąd zapewne wynikła ta pomyłka). 
Wśród 20 pozycji przechowywanych w Zakładzie Rękopisów Biblioteki Narodowej Autor wymienia też takie, których lektura nie znajduje odbicia w przypisach. Są to m.in.: R[yszarda] Michniewicza, „Historia Hufca Lidzkiego Wileńskiej Chorągwi Harcerzy w latach 1920-1939” (sygn. 11611), której przywołanie w bibliografii omawianej pracy naprawdę trudno zrozumieć. Jest to po prostu kilkudziesięciostronicowa, bogato ilustrowana wyciętymi fotografiami z gazet kronika Hufca, w żaden sposób nieporuszająca kwestii białoruskiej. (Za Białorusina omyłkowo chyba został przez J. Jagusia wzięty Polak Wacław Łastowski, dyrektor stacji doświadczalnej rolniczej i założyciel Drużyny Harcerskiej im. Władysława Łokietka w Bieniakoniach).

Znakomita praca dyplomowa wspomnianego już słuchacza Szkoły Nauk Politycznych W[ładysława] Milanowskiego nie została wykorzystana przez J. Jagusia w sposób satysfakcjonujący. Milanowski czerpał ze źródeł już dzisiaj niedostępnych w całości dla badaczy (jak archiwa Ministerstwa Rolnictwa, Referatu Osad Żołnierskich MSWojsk., a przede wszystkim dokumentacji Okręgowych Urzędów Ziemskich w Wilnie, w Grodnie, w Brześciu i w Łucku oraz Powiatowych Urzędów Ziemskich w Wilejce, Mołodecznie, Lidzie, Baranowiczach, Sarnach, Równem i Zdołbunowie). Miał też dostęp do Materiałów Związku Osadników w Warszawie przy ulicy Zielnej 22.

Jako wieloletni pracownik dokumentacji naukowej zauważę jeszcze, że autorem wymienionych w Bibliografii Wspomnień (T. I i II BN mf. 0071646) jest Bogusław Zaleski (a nie Zalewski), a Refleksje białoruskie Antoniego Mirkulewicza zostały opublikowane w „Więzi”20 jeszcze za życia ich Autora (zmarłego w 1996 roku), z czego wynika, iż J. Jaguś powinien tę pozycję po prostu umieścić w źródłach drukowanych, a nie - rękopiśmiennych.

Najczęściej przywoływanym pamiętnikarzem (co najmniej siedem razy) jest Andrzej Brochocki, barwna postać minionej epoki (autor Dziejów samoobrony w Szczuczynie Nowogródzkim: rok 1918-19), syn Władysława i Zofii (z domu Mohl) Brochockich, który jest autorem pracy „Na przełomie dwóch epok. Zapiski obszarnika”. Opisywał swoje liczne podróże (Konstantynopol, Szwajcaria, Dania, Szwecja, kolonie francuskie w Afryce, rejs Batorym), gospodarowanie we własnym Małym Możejkowie koło Lidy i charakteryzował okolicznych ziemian. Członkowie dalszej rodziny (Stanisław Gregorowicz) funkcjonujący w kręgu historyków warszawskich określają go mianem konserwatysty. Andrzejowi Brochockiemu poświęcony jest obszerny artykuł w „Ziemi Lidzkiej”.

Zygmunt Domański, absolwent Chyrowa i Uniwersytetu Jagiellońskiego (Wydziału Rolniczego), Dowborczyk, był nie tylko autorem przywoływanych Pamiętników, ale i redaktorem pisma „Wspólna Sprawa: bezpartyjny organ ziemi nowogródzkiej”, które redagował w latach 1925-1933. Pismo ostro piętnowało szkodliwą działalność urzędników administracji państwowej na Kresach. J. Jaguś cytuje Domańskiego co najmniej sześciokrotnie, ale najwyraźniej pomylił go z innym Zygmuntem Domańskim, lekarzem, który od 1927 r. był inspektorem lekarskim w Województwie Nowogródzkim ${ }^{21}$ („Z. Domański na przykład przekonany jest wręcz o całkowitej obojętności mas białoruskich na kwestie narodowe. Wspominając okres po zakończeniu I wojny światowej ów polski urzędnik pisze [--]” (s. 139)).

Józef Zaremba, autor wydanej drukiem pracy Stosunki narodowościowe w województwie nowogródzkim z uwzględnieniem tła socjalnego był m.in. nauczycielem w Gimnazjum Białoruskim w Wilnie. W 1936 r. znalazł się w Warszawie i podjął studia w Instytucie Spraw

20 A. Mirkulewicz, Refleksje białoruskie, „Więź”, R. 1991, nr 2 (388), s. 106-119.

21 Mianowany: inspektor lekarski w VI st. sł. w Urzędzie Wojewódzkim w Nowogródku Dr. Domański Zygmunt - Naczelnikiem Wydziału dnia 6. 5. 27 r. Dziennik Urzędowy MSW, tomy 10-11. 
Narodowościowych. W pracy dyplomowej opisał swoje badania prowadzone w latach 1936-1937, głównie na Polesiu. W Nowogródczyźnie prowadził je także pochodzący z artystycznej rodziny Leszek Jastrzębiec (ojciec Jan Czajewicz), legionista i żołnierz Żeligowskiego, gospodarował w majątku żony (Marii Zahorskiej) w Doli na Białorusi. Jego Pamiętnik pełen jest malarskich opisów świąt, kuligów, strojów, polowań, życia i zwyczajów ludu białoruskiego. Kazimierz Ołdziejewski, hallerczyk, autor Wspomnień Podlasianina, przed 1939 r. zatrudniony był krótko w wydziale powiatowym w Baranowiczach. Senator Józef Godlewski we wspomnieniach Na przełomie epok, wydanych po raz pierwszy w Londynie w 1978 r., m.in. opisuje czasy, gdy był właścicielem majątku Synkowicze k. Słonimia. O autorach rękopisów przywoływanych w bibliografii można by wiele jeszcze powiedzieć, a wiedza ta pozwoliłaby zrozumieć ich wyrwane z kontekstu opinie.

Niestety J. Jaguś w swoich rozważaniach nie bierze zupełnie pod uwagę ważnej metody badawczej - metody argumentum ex silentio (milczenia źródeł). Współcześni autorom przywołanych przez niego relacji inni ludzie mogli mieć inne spostrzeżenia i inne poglądy. Mogli - z premedytacją i z różnych względów - nie pozostawić swoich zapisów dla potomnych. J. Jaguś mógł też nie dotrzeć do pozostawionych przez nich świadectw lub uznać za niepotrzebną interpretację pozostawionych przez nich spuścizn.

J. Jaguś przeprowadził kwerendę w prasie - o wyborze określonych tytułów prasowych, podobnie jak w wypadku pamiętników, decydowała „intuicja autora” (s. 18). Stwierdził, iż najwięcej elementów do konstrukcji swojego obrazu Białorusinów w oczach polskich elit znalazł w „Życiu Nowogródzkim”. Szkoda, że jego „intuicja” wzięła górę nad warsztatowym przygotowaniem kwerendy. Ubóstwo tej kwerendy²2 i wybór tytułów („Gazeta Prawosławna”!) nasuwają pytanie, czy Autor - zamiast przeprowadzenia rzetelnych poszukiwań - po prostu nie wykorzystał jakiegoś przypadkowego zbioru wycinków prasowych?

Oto tytuły ukazujące się w Nowogródku i dotyczące występującej w tytule omawianej pracy Nowogródczyzny, do których należałoby zajrzeć, analizując podjęty tu temat, o których informacje, bez trudu, można znaleźć w internecie (Centralny Katalog Czasopism Polskich Biblioteki Narodowej):

1) „Ziemia Nowogródzka: regionalny tygodnik kulturalno-społeczny” wydawany w Baranowiczach, red. Tadeusz Kisielewski (1938),

2) wspomniana już wyżej „Wspólna Sprawa: bezpartyjny organ ziemi nowogródzkiej” (2.1) (red. Z. Domański) (1925-1933) z dodatkami „Szkoła Powszechna” (2.2) i „Kurier Baranowicki”(2.3),

3) „Tygodnik Nowogródzki: poświęcony sprawom społeczno-gospodarczym województwa nowogródzkiego" (red. K. Barącz) (1926),

4) „Rolnik Nowogródzki: tygodnik poświęcony sprawom wsi kresowej” (1929-1936),

5) „Gazeta Nowogródzka: wychodzi dwa razy w tygodniu” (5.1) (1934-1937) vel „Gazeta Polska Ziem Północno-Wschodnich” (5.2), red. Tadeusz Jacek Rolicki, a od 1936 r. Romuald Kawalec,

6) „Goniec Nowogródzki: tygodnik społeczno-polityczny” (1938) red. Stanisław Fiszer,

7) w Nowogródku wydawano też „Nad Niemnem: czasopismo poświęcone sprawom nowogródczyzny” (1939), red. Tomasz Obrycki,

8) w Wilnie wydawano „Naszą Wieś: czasopismo poświęcone sprawom społecznym Ziemi Wileńskiej, Nowogródzkiej i Grodzieńskiej” (1935-1936), red. Jan Dracz,

22 Ograniczył się do przejrzenia tylko trzech tytułów: wspomnianego „Życia Nowogródzkiego” (1927-1931), „Gazety Prawosławnej” (1936-1937) oraz „Ziemi Lidzkiej” (1936-1937). 
9) „Tygodnik Słonimski: pismo poświęcone sprawom ziemi słonimskiej” (1937), red. Kazimierz Harasimowicz,

10) „Gazeta Słonimska: tygodnik poświęcony sprawom społecznym, kulturalnym i gospodarczym" (1938-1939), wyd. i red. Ludmiła Nowik.

J. Jaguś deklaruje, iż przeprowadził kwerendę w 12 zespołach w AAN „które w odczuciu autora mogły zawierać dokumenty z zapisem wypowiedzi przedstawicieli polskich elit na temat Białorusinów”. Podaje nazwy następujących zespołów:

Akta Prokuratur i Sądów Województw Wschodnich

Białoruska Włościańsko-Robotnicza Hromada

Komenda Wojewódzka Policji Państwowej w Wilnie

Komitet do spraw Szlachty Zagrodowej na Wschodzie Polski

Ministerstwo Spraw Zagranicznych

Ministerstwo Rolnictwa i Dóbr Państwowych

Ministerstwo Spraw Wewnętrznych

Ministerstwo Spraw Wewnętrznych - Dopływy

Ministerstwo Wyznań Religijnych i Oświecenia Publicznego

Urząd Wojewódzki w Nowogródku 1923-1939

Zbiór Akt Starostw Powiatowych Województw Wschodnich

Zbiór Zespołów Szczątkowych.

Warto podkreślić, że wśród odnalezionych przez J. Jagusia dokumentów MSZ znajduje się perełka. Maszynopis opracowania Stanisława Ełskiego [dziś już wiemy, że to pseudonim Stanisława Łaniewskiego], wymieniony jednak wśród literatury, a nie - archiwaliów. Mowa o maszynopisie „Krótkiego zarysu zagadnienia białoruskiego w świetle historii i dobie obecnej. Kilka słów o Litwinach w Polsce” (poz. 35 „opracowań i artykułów”) opracowanym w Warszawie w 1930 r. i o ile mi wiadomo, stanowiącego pierwszą wersję (wymienionej w poz. 36 „opracowań i artykułów”) 100-stronicowej pracy tegoż autora Sprawa białoruska: zarys historyczno-polityczny wydanej w 1931 r. nakładem warszawskiej Drukarni Współczesnej23.

Trudno ustalić ile teczek Autor przejrzał. Deklaruje, iż poddał analizie co najmniej kilka tysięcy dokumentów. Wykorzystał w całej omawianej pracy w rzeczywistości około 80 dokumentów archiwalnych.

- 46 dokumentów z Urzędu Wojewódzkiego w Nowogródku 1923-1939,

- 26 dokumentów z zespołu MSW,

- 7 dokumentów MSZ,

- 2 dokumenty MWR i OP,

- dokument ze starostwa powiatowego w Lidzie,

- dokument z Komendy PP w Wilnie.

Oczywiście, nie liczba wykorzystanych dokumentów świadczy o jakości pracy. Ale zwraca uwagę fakt, iż zaledwie $13^{24}$ przywołanych dokumentów dotyczy okresu do 1926 roku.

23 St. Łaniewski [Stanisław Ełski], Sprawa białoruska: zarys historyczno-polityczny, Drukarnia Współczesna, Warszawa 1931, ss. 105.

24 Raport o stanie ogólnym na Ziemiach Wschodnich i o Sprawie Białoruskiej (1x), Stan bezpieczeństwa na terenie Województwa Nowogródzkiego w zw. z MOB - referat po Naczelnika Wydziału Bezpieczeństwa Urz. Woj. w Nowogródku (1x); Sprawozdanie z konferencji z Wojewodami z Kresów Wschodnich Ministerstwa Spraw Wewnętrznych - 14 VI 1922 (2x); Zarys programu zadań i prac państwowych na Polesiu wojewody poleskiego St. Downarowicza dn. 28 II 1923 (3x); Odpowiedź Ministra Wyznań Religijnych i Oś. Publicznego z 16 IV 1922 na interpelację z 20 I 1922 Rak-Michajłowskieg o (1x); Sprawozdanie sytuacyjno-polityczne województwa nowogródzkiego za mc maj 1923 (3x); Pismo Polskiego Towarzystwa Opieki nad Kresami do Ministra Wyznań 
Omówienie sytuacji w województwie nowogródzkim z lat 1919-1924 jest pobieżne. Jest to wynik wyraźnych luk wiedzy autora o funkcjonujących w literaturze przedmiotu opracowaniach oraz braku satysfakcjonujących efektów rozciągniętej w czasie kwerendy źródłowej.

Niestety Autor uległ sugestii E. Mironowicza (s. 25) dezawuującego konfidencjonalne źródła informacji PP. W konsekwencji warszawski Zespół PP w Wilnie (przechowywany w AAN), jak wynika z tekstu omawianej pracy, przez J. Jagusia o ile nie pominięty, to z całą pewnością niewykorzystany w stopniu, na jaki zasługuje.

Dziwi, że Autor konsekwentnie, rozciągając cezurę dwudziestolecia od roku 1919 i wykorzystując wydane już raporty Straży Kresowej z lat 1919-1920, nie uznał za stosowne przeprowadzenia poszukiwań w przechowywanych w AAN niezmiernie ciekawych dla swojego tematu (a niewydanych drukiem) raportów Towarzystwa Straży Kresowej z Nowogródka i okolic z roku 1921. Tym bardziej że wykorzystywany przez Autora zespół „Urząd Wojewódzki w Nowogródku” obejmuje (zgodnie z datą powstania) materiały dopiero od 1923 roku.

Olbrzymim mankamentem pracy dedykowanej „Województwu Nowogródzkiemu” jest ograniczenie się do zbioru AAN i nie przeprowadzenie kwerendy uzupełniającej w Wilnie. Archiwa wileńskie leżą jak najbardziej w zasięgu możliwości historyków z Polski (i znana jest ich zawartość).

W LCVA w Fondzie 119 Ap 1 (Komenda wojewódzka PP w Nowogródku) znajduje się ponad 150 teczek, a w nich raporty komendantów powiatowych o życiu politycznym 1922, spisy komunistów z 1922, korespondencja w sprawie nadzoru nad bieżeńcami (!) i liczne raporty z 1922 i 1923 (kilka teczek), teczki Komendantury PP woj. nowogródzkiego, sprawozdania sytuacyjne za lata 1924-1926 oraz korespondencja z komendantami powiatowymi w powiecie słonimskim, baranowickim i lidzkim w sprawie ruchu politycznego i życia społecznego. Jest tam również przechowywana ewidencja wybitnych działaczy społecznych i politycznych na terenie woj. nowogródzkiego.

Moskwa ze swoim zagrabionym Fondem Trofiejnym leży już poza zasięgiem możliwości przeciętnego doktoranta i dlatego jedynie wskazuję, iż m.in. informacje urzędu wojewódzkiego w Nowogródku o sytuacji na terenie województwa znajdują się tam w Fondzie 463.

W pracy J. Jagusia każdy coś znajdzie dla siebie. Wiele faktów i spostrzeżeń jest ciekawych i bez wątpienia prawdziwych, ale ich układ jest nieprzejrzysty, a do tego Autor mizernie uwzględnia znaczenie jakichkolwiek wątków przyczynowo-skutkowych.

Pisze m.in. o umacnianiu się białoruskiej świadomości narodowej pod wpływem eserów w latach 1920 i 1922 (na s. 136), by powołując się na [Białorusina] Fabjana Jeremicza [z roku 1930] ubolewać nad brakiem tej świadomości. J. Jaguś pisze o [krzywdzącym? - jgk] umacnianiu się wśród Polaków „stereotypu białoruskiej elity jako radykalnej grupy wrogo nastawionej do państwa polskiego i jednocześnie ulegającego wpływom Moskwy” (s. 73). Autor uzasadnia małą aktywność Białorusinów obawą przed represjami ze strony polskich władz (w roku 1934), a na s. 217 stwierdza „słuszność zakwestionowania tezy o spontanicznym charakterze wybuchu agresji w 1939".

Pisząc o umacnianiu się wśród Polaków „stereotypu białoruskiej elity jako radykalnej grupy wrogo nastawionej do państwa polskiego i jednocześnie ulegającego wpły-

Religijnych i Oświecenia Publicznego z dn. 31 sierpnia 1923 (1x); Sprawozdanie sytuacyjno-polityczne województwa nowogródzkiego za mc październik 1923 (2x); Protokół obrad na zjeździe Wojewodów w dniu 5-6 stycznia roku 1925 (100 część jawna) (233, 239 część tajna) (3x); Protokół zjazdu starostów woj. nowogródzkiego z dnia 17 i 18 lutego 1925 pod przew. wojew. M. Januszajtisa (5x); Protokół obrad na zjeździe Wojewodów Ziem Wschodnich 19-20 X 1925 (5 x); Sprawozdanie z działalności białoruskich organizacji w Polsce za 1925 (1 x). 
wom Moskwy", Autor po prostu nie wie, że informacje o antypolskich działaniach BRL, które miały miejsce co najmniej od lata 1918 r. docierały nie tylko do Komisji Litewskiej Tymczasowej Rady Stanu, ale i na Nowogródczyznę (a z całą pewnością dotarły do ludzi, którzy na Nowogródczyznę przybyli po 1921 r.). Te informacje - po prostu - skutkowały po latach. Gdyby Autor rzetelnie przejrzał akta PP w AAN w Warszawie, to wiedziałby, że komendy policji na wschodzie kraju otrzymały w 1924 r. informacje z Komendy w Wilnie o tekście umowy zawartej w Mińsku 17 marca 1923 r. pomiędzy przebywającymi na terytorium Litwy przedstawicielami białoruskich socjalrewolucjonistów, białoruskich socjaldemokratów i białoruskich socjalfederacjonistów a pełnomocnikami Białoruskiej SSR. Umowa Mińska zawarta pomiędzy Zmicierem Żyłunowiczem i Usiewałodem Ignatowskim (pełnomocnikami Białoruskiej Socjalistycznej Sowieckiej Republiki) a Aleksandrem Gołowińskim, Aleksandrem Walkowiczem i Gołubincewem (legitymujących się pełnomocnictwami Białoruskiej Partii Socjal-Rewolucyjnej; Białoruskiej Partii Socjal-Demokratycznej oraz Białoruskiej Partii Socjal-Federacjonistów), której odpisem dysponowała strona polska, była tajna, ale jej mrożąca dla Polaków treść ${ }^{25} \mathrm{w}$ ogólnym zarysie znana była szerokiemu gronu elit polskich, do których J. Jaguś zalicza przecież i policjantów. Tekst „Krótkiego zarysu zagadnienia białoruskiego” opracowanego przez funkcjonariuszy Służby Informacyjnej w 1924 r. w Wilnie znajduje się również w AAN w Warszawie.

Dysponując pracą dyplomową Milanowskiego, J. Jaguś rozporządzał unikalnymi danymi statystycznymi dla województwa nowogródzkiego, których nie tylko nie zinterpretował należycie, ale po prostu pominął milczeniem lub - za badaniami Zaremby - podał wyrywkowo i bezrefleksyjnie (s. 34). Mnie jednak zaciekawiły np. dane dotyczące przyrostu mieszkańców miast Ziemi Nowogródzkiej. Z samego sposobu zestawienia tabel jasno wynika, że istotną grupą tzw. innej narodowości w Nowogródczyźnie, z punktu widzenia ówczesnych polskich naukowców, bynajmniej nie była grupa białoruska. Miast, w których ludność rolnicza stanowiła, według Autora, znaczący procent (21\% - patrz przypis 20, s. 34$)$.

Województwo nowogródzkie. Przyrosty ludności miejskiej wg Milanowskiego

\begin{tabular}{|l|r|r|r|}
\hline Miasto & Przyrost ludności polskiej & Przyrost ludności pozostałej & Przyrost ludności żydowskiej \\
\hline Baranowicze & $-18,50 \%$ & $-29,9 \%$ & $-20,6 \%$ \\
\hline Lachowicze & $+33,70 \%$ & $+33,6 \%$ & $+33,7 \%$ \\
\hline Lida & $+45 \%$ & $+45,3 \%$ & $+45,4 \%$ \\
\hline Nieśwież & $+4,6 \%$ & $+6 \%$ & $+6,5 \%$ \\
\hline Kleck & $+9,3 \%$ & $+7,8 \%$ & $+7 \%$ \\
\hline Nowogródek & $+50,3 \%$ & $+50 \%$ & $+50,3 \%$ \\
\hline
\end{tabular}

25 Bez ogródek mówiono o długoterminowym celu porozumienia: „Sprawy zagraniczne winny pójść nadal tą samą koleją, należy jedynie położyć specjalny nacisk, by państwa zachodnie patrzyły na tę sprawę nie jak na akcję bolszewicką, a jak na akcję narodowo-białoruską, jak gdyby rząd Łastowskiego nie ma nic wspólnego z bolszewikami i Mińskiem. W przeciwnym razie nie będziemy mogli uzyskać [uznania?] zagranicy, o co tak długo się dobijamy”. Umowa obejmowała też ustalenia co do bieżącej taktyki. Ze względu na „chwilę zupełnego spokoju na zewnątrz" ustalono bezwzględne wstrzymanie - na razie - planowanych zbrojnych powstań na terenie Polski, które mogłyby „popsuć jedynie sprawę”. Zakładano, iż w korzystnym momencie (w razie nieuniknionej wojny) nieduża garstka białoruskich partyzantów będzie znajdowała się na terenie Litwy i wspierała akcję armii sowieckiej. W sprawie rządu przyszłej niepodzielnej Białorusi pozostać miała w mocy umowa podpisana przez Łastowskiego w listopadzie 1919 r. 


\begin{tabular}{|l|r|r|r|}
\hline Miasto & Przyrost ludności polskiej & Przyrost ludności pozostałej & Przyrost ludności żydowskiej \\
\hline Zdzięcioł & $+21,6 \%$ & $+21,6 \%$ & $+21,6 \%$ \\
\hline Słonim & $+69,9 \%$ & $+48,3 \%$ & $+53,5 \%$ \\
\hline Stołpce & $+122,2 \%$ & $+11 \%$ & $+112,4 \%$ \\
\hline Wołożyn & $+54 \%$ & $+44 \%$ & $+38 \%$ \\
\hline
\end{tabular}

Nawiasem mówiąc, lektura pozostałych zestawień podanych przez Milanowskiego m.in. w dziesięciu tabelach/wykresach daje pole i do wielu innych, ciekawych spostrzeżeń.

„Stereotyp Białorusina w oczach Polaków” (począwszy od 1918 r.) został omówiony przez J. Jagusia na stronach 172-173 pracy, gdzie Autor przedstawia Katalog cech charakterystycznych dla Białorusinów według polskich elit. Cechy wymienione są przez niego alfabetycznie [!] i... wzajemnie się wykluczają, czego Autor bynajmniej nie komentuje. W największym skrócie Białorusin był osobą: apatyczną, zacofaną, cichą, bierną, nietwórczą, niezaradną, powolną, posłuszną i zamkniętą w sobie. Z jednej strony miał być masą oporną wobec nowinek, a z drugiej - łatwo miał dawać sobą kierować. Ta sama „masa” - zgodnie z Katalogiem cech... - miała być inteligentna, $\mathrm{z}$ natury spostrzegawcza i zdroworozsądkowa, a także chytra, o bardzo silnym poczuciu własnego interesu. Charakteryzować ją miała skłonność do nadużywania alkoholu i bardzo silne poczucie sprawiedliwości, a także pragnienie i oczekiwanie dalszych zmian. „Masę” tę cechowała ponadto nieumiejętność myślenia kategoriami państwowymi.

Być może autorskie zestawienie tych (i pozostałych) mechanicznie wymienionych cech zmusiłoby J. Jagusia do zastanowienia nad sensem historii, w której dynamika wydarzeń zmienia bardzo wiele, o ile nie wszystko. A także do zastanowienia nad innym kształtem własnej pracy.

Reasumując. „Ludność białoruska” wiosną 1919 r. to nie ta sama ludność, która w wyniku akcji wyborczej do (polskiego) Sejmu I kadencji poznała swoich politycznych liderów. To nie ta sama ludność, która tłumnie zasilała szeregi KPZB. Wreszcie, to nie ta sama ludność, która mordowała sędziwych Skirmuntów w Mołodowie.

Razi sposób posługiwania się źródłami i konsekwentne ignorowanie chronologii zdarzeń i ciągów przyczynowo-skutkowych. Były jednak cezury. Rok 1919, 1924, zamach majowy, Hromada, śmierć Piłsudskiego... Uważam, że nie można tak nonszalancko zestawiać źródeł powstałych w różnych sytuacjach w odstępie kilkunastu lat ${ }^{26}$ !

Wiele uwag Autora jest dla mnie niejasnych. Na s. 129 zupełnie niezrozumiały jest przypis 80 . O wynik jakiego plebiscytu mogli być spokojni Polacy za wojewody [Adama Korwin -] Sokołowskiego, który pełnił tę funkcję od 17 grudnia 1935 do 17 września 1939? Przypomnę. Ententa rzeczywiście zabroniła Polsce przeprowadzenia zapowiedzianego w Odezwie Wileńskiej (1919, kwiecień) i planowanego samookreślenia mieszkańców Ziem Wschodnich (inaczej plebiscytu), ale stało się to na długo przed objęciem funkcji wojewody przez Sokołowskiego - 6 marca 1920! Potem przeprowadzenia plebiscytu nie brano już pod uwagę.

Brak rudymentarnych danych o autorach przywoływanych dokumentów nie jest odosobniony. Nazwiska postaci z epoki pojawiające się w przytaczanych dokumentach „Białorusin Aleksiuk”, „polscy urzędnicy” (mowa o Władysławie Raczkiewiczu i Marianie Józefie Żegota

$26 \mathrm{Na}$ s. 123 w przypisie 64 omawia fragment sprawozdania z połowy 1933 r. dotyczący wycieczki dla Białorusinów po Polsce i uzupełnia ten akapit cytatem z Ruszczyca na temat innej wycieczki z 1922 roku. 
- Januszajtisie) „polskiej administracji” (np. s. 256) powinny coś mówić dr. Jagusiowi. Z całą pewnością nie będą jednak mówiły niczego czytelnikowi jego pracy, nieprzygotowanemu merytorycznie do lektury. Opracowanie przypisów osobowych do takich postaci, jak czołowy białoruski polonofil Paweł Aleksiuk, wojewoda i były Naczelnik Okręgu Mińskiego ZCZW słynący z probiałoruskich zachowań w 1919 r. czy niedoszły zamachowiec na rząd Jędrzeja Moraczewskiego ze stycznia 1919 r. wydaje mi się po prostu konieczne. „Wojewodzie Sokołowskiemu” tez można by przywrócić imię i zawołanie. Wyliczać szczegóły można by długo.

J. Jaguś, nie mając wystarczającej wiedzy dotyczącej wydarzeń z lat 1919-1920, które to lata postanowił ująć w swojej analizie, pisze (s. 7): „odtworzenie sposobu postrzegania Białorusinów przez Polaków w znacznym stopniu ułatwi zrozumienie wielu postaw i zachowań mniejszości białoruskiej w dwudziestoleciu”, zaczyna „odtwarzać” wspomniany sposób postrzegania Białorusinów od „trzeciego rozdziału”! Żongluje wybranymi urywkami posiadanej wiedzy ze „źródeł zastanych”, by omówić problem historycznej genezy zjawiska na podstawie niepełnej historycznie wiedzy. Uwadze J. Jagusia przy analizie podjętego przez siebie tematu umknął całkowicie polityczny i historyczny kontekst rekonstruowanych emocji.

Źródła użyte przez J. Jagusia w poświęconej województwu nowogródzkiemu książce nie tyle są „zastane”, ile bardzo niestarannie szukane! Nie dość dokładna kwerenda, brak rzetelnego historycznego fundamentu sprawiają, że praca ta - w moim odczuciu - utrwala „socjologiczny” stereotyp „całkowicie bezpodstawnie negatywnego stosunku bogatej elity Polaków do pokrzywdzonych Białorusinów”. Stereotyp utrwalany przez historiografię opublikowaną dotychczas w Polsce, stereotyp bynajmniej nie odkrywczy, a w dalszej perspektywie - szkodliwy. Dopiero w małym eseju - zakończeniu (jakby inną ręką kreślonym) - Autor sygnalizuje, iż Polacy dostrzegali negatywnie oceniane białoruskie elity w odróżnieniu od pozytywnie ocenianych, mało mobilnych białoruskich mas. (J. Jaguś pisał już o tym wcześniej: „Obraz zarysowany [--] w zasadniczych jego tezach zgadza się z obrazem Białorusina zaprezentowanym przez Ryszarda Radzika czy Jana Jurkiewicza” (J. Jaguś, 2010 [patrz przypis 12, s. 59])). Przechodzi jednak nad tą konstatacją do porządku, dodając szybko: „Uwzględniając fakt, że ideologiczny charakter spajających daną wspólnotę więzi generuje postawy charakteryzujące się ekspansywizmem i aktywizmem, przywołany sposób postrzegania cech osobowych Białorusinów jest więc zasadniczo komplementarny wobec poprzednio opisanych elementów krajobrazu" (s. 257).

Niestety Autor odstąpił od deklarowanego w zwiastunie tej dysertacji celu pracy: „Doniosłe badawczo byłoby zbadanie kwestii ewentualnych różnic w postrzeganiu Białorusinów w II Rzeczpospolitej w poszczególnych rejonach Polski oraz przez poszczególne kategorie społeczno-zawodowe Polaków” (J. Jaguś, 2010 [patrz przypis 12, s. 59]).

Biorąc tę pracę do ręki, liczyłam, iż lektura, w oparciu o casus Nowogródczyzny w latach 1918-1939, przybliży mnie do odpowiedzi na pytanie o możliwość integracji w dobie budzenia się tożsamości kulturowej w poszczególnych grupach społeczeństwa byłego Wielkiego Księstwa Litewskiego. Ciekawa by była m.in. próba ustalenia, na ile budząca się tożsamość kulturowa wyklucza jakąkolwiek integrację, czy jest możliwe (i na jakich warunkach) współżycie narodowości pozostających w odmiennych stadiach rozwoju.

Konkludując. Nie kwestionuję w tym tekście zasady badania jednego zjawiska przy pomocy warsztatu naukowego różnych dyscyplin. Jednak - primum non nocere. Należy warsztat naukowy każdej z dyscyplin stosować poprawnie. Jestem przedstawicielką pokolenia badaczy wykształconego w duchu szacunku dla metodyki własnej specjalizacji i unikania rażących sprzeczności w trakcie posługiwania się metodologią innych specjalizacji. 
Praca dr. Jacka Jagusia w swym założeniu jest monografią o charakterze interdyscyplinarnym, którą - z punktu widzenia historyka - charakteryzują istotne luki w znajomości dostępnej literatury przedmiotu i bardzo niestaranna kwerenda archiwalno-biblioteczna. W moim odczuciu praca ta jest klasycznym przykładem bezrefleksyjnego zastosowania źle przyswojonej metodologii nauk historycznych w pracy socjologicznej.

Lektura tego doktoratu skłoniła mnie również do zastanowienia się nad celowością systemu panującego od ostatnich kilku lat w nauce. Bez deklarowanej interdyscyplinarności nie ma szans na uzyskanie takiej czy innej dotacji do badań. Coraz krótsze są terminy na wykonanie prac i coraz wyższe oczekiwania co do syntetyczności wyciąganych wniosków. Źle zrealizowany temat (co zawsze może się zdarzyć) ma małe perspektywy, by otrzymać jeszcze raz szansę (czytaj dotację) na ponowne podjęcie nad nim studiów. Czy to wszystko - w dalszej perspektywie - nie obniży poziomu nauki?

Joanna Gierowska-Kałłaur (karp24@wp.pl) 